\title{
Roasted Olive Stones powder: Promising Alternative of non-Caffeinated Coffee
}

\author{
Mounir M. Eid, Safaa E. Ali, Dalia M. M. Mostafa and Muhammad E. Elsorady \\ Food Technology Research Institute, Agricultural Research Center, Giza, Egypt. \\ *Corresponding author E- mail: mounireid@hotmail.com
}

\begin{abstract}
Olive stones are the main byproduct of table olive industry which usually discarded as materials with no use or value. The lack of uses for this by-product for human food constitutes a real economic loss since it is rich in dietary fiber, phenolic compounds and antioxidants .An overview of the characterization and main uses of roasted olive stones powder are described for the first time. In this way, a new approach to the olive stones is described to produce innovative healthy alternative coffee brew. The present work was investigated to study the effect of roasting time (25 and $50 \mathrm{~min}$ ) on physical, chemical parameters and quality characteristics of roasted olive stones powder (ROSP) which can be used as coffee-like brew. The physicochemical and quality attributes were significantly influenced by the roasting time. It could be recommended that the ROSP as coffee-like brew had acceptability through the sensory evaluation.
\end{abstract}

Keywords: Olive stone, roasting, Alternative coffee brew, antioxidant, sensory evaluation 
INTERNATIONAL JOURNAL OF

FAMILY STUDIES, FOOD SCIENCE AND NUTRITION

HEALTH

VOLUME 4, ISSUE 2, 2021, $110-123$.

www.egyptfuture.org/ojs/

\section{Introduction}

Olive (Olea europaea L.) is one of the most crops in the Mediterranean region which used to produce olive oil and table olive products. Table olives are one of Egypt's important appetizers (Elsorady, 2010). The world production of table olives is 2961 thousand tons (2019/2020), according to the recent International olive council (IOC) report (IOC, 2021), Egypt accounted for approximately $22 \%$ of the world table olive production over that time. Egypt ranked first in the world in the production of table olives, with production of 650 thousand tons over that time. Egypt consumption is $20 \%$ of world consumption of table olives (IOC, 2021). In the meantime, Egypt has plans to plant about 100 million olive trees by 2022 as part of the country's project of the cultivation of the 1.5 million feddans.

During table olive industry, olives may be offered in stoned (pitted) olives style. Therefore, the stone (pit) constitute the main byproduct of table olive industry. Olive pits contain phenolic compounds, flavonoids and secoiridoids (Maestro-Durán et al., 1994; Servili et al. 1999). The whole stone consists of the wood shell (stone) and the seed. Cellulose, hemicellulose, lignin, fat and protein are the main components of this byproduct (Rodríguez et al. 2008). Olive stones were applied in many applications such as combustion (Gonzalez et al., 2003), activated carbon (Sanchez et al., 2006), liquid and gas production (Putun et al., 2005), olive seed oil (Luaces et al., 2003), furfural (Montane' et al., 2001), plastic filled (Siracusa et al., 2001), animal feed (Carraro et al., 2005).

Coffee is growing in over 70 countries, mainly in Latin America, Asia, and Africa. World coffee production in 2020/2021 was 175.5 million bags ( 1 bag $=60$ kilogram $)$ ap. 10.5 million tones, Brazil and Colombia contributes to $40 \%$ of this annually production. Egypt imports of coffee seeds has increase from 630 thousand bags in 2016/2017 to 825 thousand bags in 2020/2021 costing 127.7 million dollars/year (USDA Foreign Agricultural Department, 2020). Coffee is one of the most important consumed drinks all over the world and caffeine source for human (Reyes and Cornelis, 2018). Sensory quality of coffee has influenced by roasting (Münchow et al., 2020). Coffee consumption provides health benefits against diseases such as diabetes, Parkinson disease and cancer while higher coffee consumption is associated with stroke, hypertension and minerals deficiencies. Caffeine consumption is negatively associated with calcium levels and increased risk of fractures (Ahsan and Bashir, 2019).

Although caffeine is used daily it is still an addictive drug whose consumption must be limited. Hence an alternate natural substance that looks tastes and smells like coffee that has no health risk is very much needed. Virtually, it is the first time to use the roasted olive stone powder (ROSP) for preparation of an alternative coffee brew. Thus, the primary objective of this work is to introduce, popularize and evaluate roasted olive stone powder for preparation of an innovative healthy, non-Caffeinated, low cost alternative brew to coffee to avoid negative health impacts. 


\section{Material and methods:}

The main material for this innovative drink is olive stones (Aggizi Shami cultivar) which were taken as a waste from pickling unit at Food technology research institute, Agriculture research center, Giza, Egypt.

Light roasted flavorings coffee, medium roasted flavorings coffee and ingredients used for preparing ROSP brew (cardamom, button roses, nutmeg and cloves) were obtained from local market. Also, all reagents used were of analytical grade or higher available purity.

\section{Preparation of olive stones}

Olive stones were boiled in ordinary tap water for 1 hour using a hot plate (Thermo Fisher Scientific Aluminum-Top Hotplates) to remove any adhering residuals and any traces of pickling solution, then washed. Before roasting process, olive stones samples were placed on aluminum foil and spread as a thin layer on stainless steel trays. Drying was carried out using convection oven (Thermo Fisher Scientific Oven) at temperature at $60{ }^{\circ} \mathrm{C}$ for $1 \mathrm{~h}$ to remove excess water from stone surface. After that olive stones were roasted in convection oven at 200 - $\mathrm{C}$. for 25 and 50 min was used until the olive stones get light brown color and roasting aroma. After roasting, olive stones were allowed to cool at room temperature.

\section{Preparation of roasted olive stones powder (ROSP)}

Adequate amount of roasted olive stones were ground by using commercial coffee grinder (Mikal,Japan coffee grinder NCG- 904 ) to produce a fine powder. As well as milled flavorings of traditional brewed Egyptian coffee (cardamom 2.5\%, button roses 4\%, nutmeg $0.5 \%$ and cloves $0.5 \%$ ) were add to olive stones powder for sensory evaluation test. The ground ROSP samples were placed in sealed polyethylene bags and stored in a refrigerator maintained at $7 \pm 2{ }^{\circ} \mathrm{C}$ in order to avoid moisture absorption and to minimize any enzyme activity of the powder to avoid deterioration (Figure 1). 


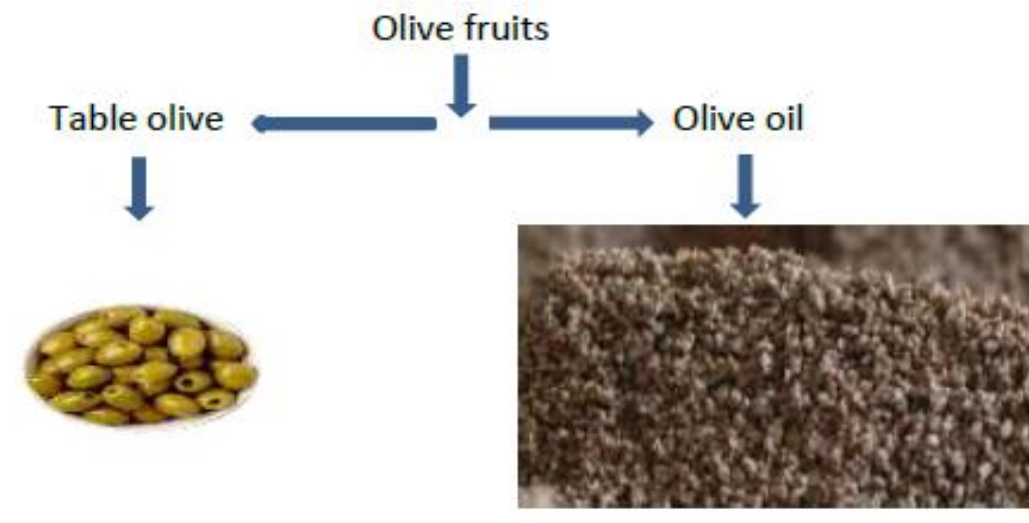

Pitted olives

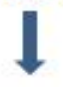

Olive stone

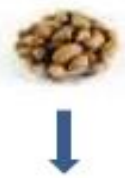

Roasting

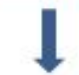

Grinding

$\downarrow$

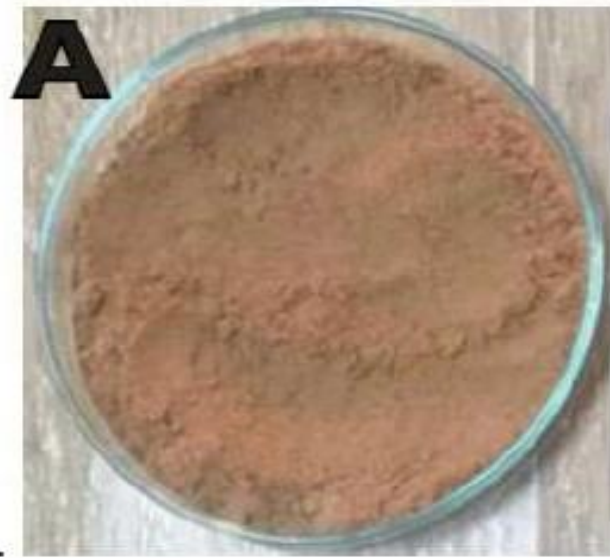

Olive pomace

De-stoning

Olive stone

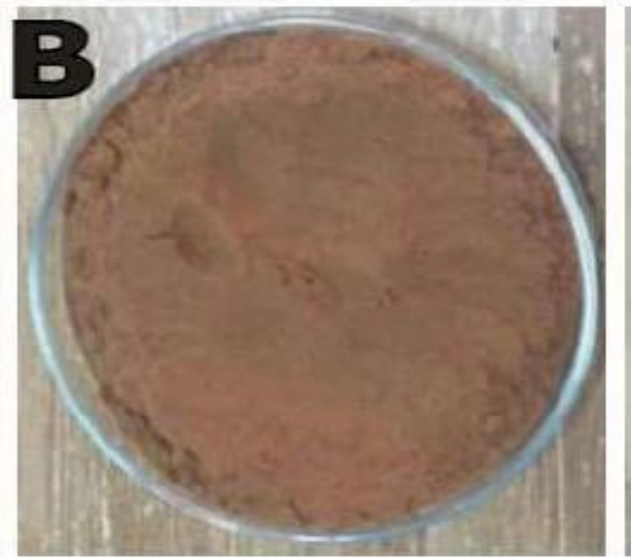

Figure (1): Flow chart of production of ROSP

A: Roasted at $200^{\circ} \mathrm{C} / 25 \mathrm{~min}, \mathrm{~B}$ : Roasted at $200^{\circ} \mathrm{C} / 50 \mathrm{~min}$ 


\section{Proximate composition}

Moisture content, ash, fat, fiber, and protein were determined using the method of AOAC (2012) and total carbohydrates were determined by difference.

\section{Minerals content of ROSP}

Minerals content such as Sodium (Na), Magnesium (Mg), Potassium (K), Zinc (Zn), Calcium $(\mathrm{Ca})$, Iron $(\mathrm{Fe})$ and Copper $(\mathrm{Cu})$ were determined for ROSP using an Atomic Absorption Spectrometry (GBC Avanta E, Victoria, Australia) according to AOAC (2012).

\section{Bulk density of ROSP}

The volume of ROSP (100 g) was measured using a measuring cylinder (1L). ROSP was filled into the cylinder without compacting. The ratio of mass to volume of ROSP in the cylinder was calculated as bulk density (Gikuru and Jindal, 2003).

\section{Quality indicators of ROSP}

The ROSP (1g) was extracted with $50 \mathrm{ml}$ of boiling distilled water for $2 \mathrm{~min}$ using a magnetic stirrer. The extract was filtered to investigate the quality indicators (extraction yield, $\mathrm{pH}$, acidity and browning index).

The filtrate was frozen and freeze-dried. The amount of freeze-dried solids in relation to the amount of ground ROSP used gives the extraction yield (\%, w/w) [Eq. (1)] (Lopes et al., 2020)

freeze dried solid $(\mathrm{g})$

Extraction yield $(\% \mathrm{w} / \mathrm{w})=$

The $\mathrm{pH}$ of the extract was determined with a $\mathrm{pH}$ meter, Model accumet ${ }^{\circledR}$ Fisher Scientific $\mathrm{pH}$ meter 25 (USA), according to the instruction manual of the apparatus. The acidity was determined by titrating $10 \mathrm{ml}$ of extract against $0.01 \mathrm{~N}$ sodium hydroxide using phenolphthalein as an indicator and the results were expressed as a percentage of citric acid.

\section{Browning Index of ROSP}

ROSP extract $(50 \mu \mathrm{L})$ was diluted up to $2 \mathrm{~mL}$ with demineralized water. The browning index was measured by using spectrophotometer (UV1601; Shimadzu, Kyoto, Japan) at $420 \mathrm{~nm}$ (Benjakul et al., 2005). This index indicates the browned compounds resulting from caramelization and Maillard reactions, including melanoidins.

\section{Phytochemical characteristics of ROSP}

The total phenol content (mg GAE/g) of the extracts was determined using FolinCiocalteau reagent according to $\mathrm{Xu}$ and Chang (2007). The total flavonoid content (mg quercetin/g) was determined according to Eghdami and Sadeghi (2010). 2,2-Diphenyl-1picrylhydrazyl (DPPH) antioxidant assay was performed based on the modified method of Liu $\boldsymbol{e t}$ al. (2008). 
INTERNATIONAL JOURNAL OF

FAMILY STUDIES, FOOD SCIENCE AND NUTRITION

HEALTH

VOLUME 4, ISSUE 2, 2021, $110-123$.

www.egyptfuture.org/ojs/

The antioxidant activity of the sample was determined based on Eq. (2):

$\%$ DPPH Scavenging $=[(\Delta$ A517 of control $-\Delta$ A517 of sample $) / \Delta$ A517 of control $]$.

\section{Color measurement of ROSP}

The color of ROSP was measured by the Hunter Lab Colorimeter, (Hunter Associates Laboratory, Inc., Virginia, USA). The test was carried out in triplicates.

\section{Determination of fatty acids composition:}

Fatty acids of ROSP oil was determined using Agilent 6890 Gas chromatography according to the methods of Eid et al. (2012).

\section{Determination of phenol compounds:}

Phenol compounds in ROSP were determined by HPLC according to the method described by Peres et al. (2016).

\section{Preparation of ROSP brew:}

ROSP brew was prepared as authentic Egyptian coffee using a coffee pot (kanaka), The ROSP brew was prepared using the tap water $80 \mathrm{ml}$ (coffee cup). Two spoons flavored ROSP $(12 \mathrm{~g})$, one sugar spoon $(5 \mathrm{~g})$ were added. These ingredients were mixed until combined and then heat in a stove until boiling (2-3 minutes) to get the brew. The brew was analyzed for sensory properties.

\section{Sensory evaluation of ROSP brew:}

The sensory evaluation of ROSP brew was assessed to determine the acceptability of the product. ROSP brew was presented in cups with different coding numbers and served hot to ten trained panelists (5 males and 5 females) (staff members in Food Technology Research Institute). Panelists were asked to score color; taste; odor and overall acceptability of new product using the nine-point hedonic scale and compared with coffee control samples. Tap water was provided between samples to cleanse the palate (Larmond, 1997).

\section{Statistical analysis}

Statistical analyses were conducted using the SPSS program version 16.0.

\section{Result and Discussions}

Analysis is widely accepted as a basis for nutritional evaluation of food. The proximate chemical composition of ROSP was studied and presented in Table (1). The chemical composition of ROSP agreed with those obtained by Rodriguez et al (2008) and Bianchi, (2003). Roasting time has a significant difference on proximate composition except ash. Results revealed that moisture; fat, crude fiber and ash of ROSP were decreased from 10.56, 7.36, 16.66, 0.85\% to 2.04, 5.98, 13.64, and $0.82 \%$; respectively with increasing roasting time from $25 \mathrm{~min}$ to $50 \mathrm{~min}$ at $200^{\circ} \mathrm{C}$. On the other hand, crude protein and total carbohydrates were increased with increasing roasting time. 
INTERNATIONAL JOURNAL OF

FAMILY STUDIES, FOOD SCIENCE AND NUTRITION

HEALTH

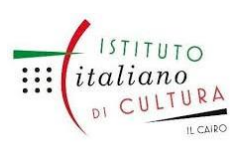

ISSN: $2735-5381$

VOLUME 4, ISSUE 2, 2021, $110-123$.

www.egyptfuture.org/ojs/

Table (1) Proximate analysis (\% as of dry weight) of ROSP

\begin{tabular}{|c|c|c|}
\hline Constituent (\%) & Roasted at $200^{\circ} \mathrm{C} / 25 \mathrm{~min}$ & Roasted at $200^{\circ} \mathrm{C} / 50 \mathrm{~min}$ \\
\hline Moisture & $10.56 \pm 0.21^{\mathrm{a}}$ & $2.04 \pm 0.03^{b}$ \\
\hline Crude protein $(\mathrm{Nx} 6.25)$ & $3.70 \pm 0.08^{a}$ & $4.5 \pm 0.07^{b}$ \\
\hline Fat content & $7.36 \pm 0.11^{\mathrm{a}}$ & $5.98 \pm 0.09^{b}$ \\
\hline Crude fiber & $16.66 \pm 0.14^{a}$ & $13.64 \pm 0.08^{b}$ \\
\hline Ash & $0.85 \pm 0.05^{a}$ & $0.82 \pm 0.03^{a}$ \\
\hline Total carbohydrates & $60.87 \pm 0.59^{a}$ & $73.02 \pm 0.30^{b}$ \\
\hline
\end{tabular}

- Different letters on same represent statistically significant $(\mathrm{P}<0.05)$ difference between means

Minerals composition of ROSP is illustrated in Table (2). The data clearly show that ROSP are considered a rich source of minerals. ROSP for 50 min contained higher significantly contents of $\mathrm{Na}, \mathrm{K}, \mathrm{Zn}, \mathrm{Ca}, \mathrm{Fe}$ and $\mathrm{Cu}$ than ROSP for $25 \mathrm{~min}$. This is may be related to loss of moisture during roasting.

Table (2) Mineral content (mg/Kg) of ROSP

\begin{tabular}{|c|c|c|}
\hline Element & Roasted at $200^{\circ} \mathrm{C} / 25 \mathrm{~min}$ & Roasted at $200^{\circ} \mathrm{C} / 50 \mathrm{~min}$ \\
\hline $\mathrm{Na}$ & $3320.24 \pm 15.14^{\mathrm{a}}$ & $3428.03 \pm 17.24^{b}$ \\
\hline Mg & $248.12 \pm 6.02^{a}$ & $258.88 \pm 6.69^{a}$ \\
\hline $\mathbf{K}$ & $240.98 \pm 2.83^{\mathrm{a}}$ & $1210.53 \pm 7.71^{b}$ \\
\hline $\mathbf{Z n}$ & $15.17 \pm 0.27^{\mathrm{a}}$ & $21.42 \pm 0.12^{b}$ \\
\hline $\mathbf{C a}$ & $4391.33 \pm 11.85^{a}$ & $5070.53 \pm 9.31^{\text {b }}$ \\
\hline $\mathbf{F e}$ & $36.32 \pm 0.37^{\mathrm{a}}$ & $79.45 \pm 0.48^{b}$ \\
\hline $\mathbf{C u}$ & $6.24 \pm 0.12^{a}$ & $10.71 \pm 0.29^{b}$ \\
\hline
\end{tabular}

- Different letters on same represent statistically significant $(\mathrm{P}<0.05)$ difference between means

Bulk density of ROSP at different roasting times is presented in Table 3. The bulk density of ROSP was significantly $(\mathrm{P}<0.05)$ affected by roasting time. The bulk density was decreased from 0.866 to $0.679(\mathrm{~g} / \mathrm{cm} 3)$ with increasing roasting time. This is related to the volume increments of ROSP with time due to expansion of the tissue particles while loose moisture, as roasting time increases. These results agreed with Gikuru and Jindal (2003); Anisa et al. (2017); Fikry et al. (2019). The bulk density of olive stone flour is 1.2, which is quite lower than that of lignocellulosic fibers (1.5-1.6) (Bledzki and Gassan, 1999).

Table (3) Bulk density and quality attributes of ROSP

\begin{tabular}{|c|c|c|}
\hline Parameters & Roasted at $200^{\circ} \mathrm{C} / 25 \mathrm{~min}$ & Roasted at $200^{\circ} \mathrm{C} / 50 \mathrm{~min}$ \\
\hline Bulk density (g/cm3) & $0.866 \pm 0.001^{\mathrm{a}}$ & $0.679 \pm 0.002^{b}$ \\
\hline Extraction yield (g/100g) & $0.45 \pm 0.05^{\mathrm{a}}$ & $0.89 \pm 0.06^{b}$ \\
\hline PH at $20^{\circ} \mathrm{C}$ & $6.18 \pm 0.02^{\mathrm{a}}$ & $5.16 \pm 0.05^{b}$ \\
\hline $\begin{array}{c}\text { Acidity as citric acid } \\
(\mathrm{mg} / \mathbf{1 0 0 g})\end{array}$ & $20.0 \pm 0.15^{a}$ & $41.6 \pm 0.15^{b}$ \\
\hline $\begin{array}{l}\text { Browning index Abs. at } \\
420 \mathrm{~nm} .\end{array}$ & $0.028 \pm 0.003^{a}$ & $0.042 \pm 0.002^{b}$ \\
\hline
\end{tabular}

- Different letters on same represent statistically significant $(\mathrm{P}<0.05)$ difference between means 


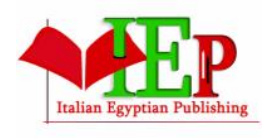

ISSN: $2735-5381$
INTERNATIONAL JOURNAL OF

FAMILY STUDIES, FOOD SCIENCE AND NUTRITION

HEALTH

VOLUME 4, ISSUE 2, 2021, 110-123.

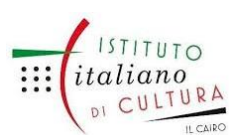

www.egyptfuture.org/ojs/

The mass of soluble solids in the extract was defined as extraction yield. Data in Table (3) showed that extraction yield increased from 0.45 to $0.89(\mathrm{~g} / 100 \mathrm{~g})$ with roasting time increment. This could be due to the porosity increment of ROSP structure. During roasting, the $\mathrm{pH}$ decreased significantly with increment of roasting time to $50 \mathrm{~min}$ (Table 3 ) and the acidity significantly increased in ROSP as a result of decreased moisture and possibly due to hydrolysis of some of the organic acids present in ROSP. This is may be related to decomposition of some of the organic acids in the ROSP. These results agreed with Fikry et al. (2019).

Non-enzymatic browning reactions such as maillard reaction and sugar caramelization occurring during the roasting process, which enhance the development of brown pigments, consequently give the product a darker color (Massini et al., 1990; Özdemir and Devres, 2000). Browning index was significantly increased from 0.028 to 0.042 with roasting time increment (Table 3). These results agreed with Fikry et al. (2019).

Phenolic and flavonoid compounds are significant bioactive components which had beneficial effects such as antioxidant, anti-carcinogenic, antimicrobial, anti-inflammatory activities, and the reduction of cardiovascular disease (Shahidi and Naczk, 2004). The results of the total phenolic and flavonoids contents are shown in Table 4. The total phenol and flavonoids contents were higher in ROSP for 50 min than those roasted for 25 min. Roasting plays an important role in the oxidation process for producing unknown substances by the Maillard reaction increased the content of polyphenols. There were significantly differences in total phenols and flavonoids contents with the different roasting time $(p<0.05)$.

Table (4) Phytochemical and color characteristics of ROSP

\begin{tabular}{|c|c|c|c|c|c|}
\hline & Constituent & \multicolumn{2}{|c|}{ Roasted at $200^{\circ} \mathrm{C} / 25 \mathrm{~min}$} & \multicolumn{2}{|c|}{ Roasted at $200^{\circ} \mathrm{C} / 50 \mathrm{~min}$} \\
\hline Tota & Is content $(\mathrm{mg} / \mathbf{1 0 0 g})$ as $\mathrm{GAE}$ & \multicolumn{2}{|c|}{$121.30 \pm 6.10^{a}$} & \multicolumn{2}{|c|}{$222.50 \pm 3.20^{b}$} \\
\hline \multicolumn{2}{|c|}{$\begin{array}{c}\text { Total flavonoids content }(\mathrm{mg} / 100 \mathrm{~g}) \text { as } \\
\text { quercetin }\end{array}$} & \multicolumn{2}{|c|}{$115.90 \pm 2.30^{a}$} & \multicolumn{2}{|c|}{$206.2 \pm 3.10^{b}$} \\
\hline \multirow{3}{*}{\multicolumn{2}{|c|}{ DPPH Radical Scavenging Activity (\%) }} & $\begin{array}{c}0.1 \mathrm{ml} \\
(10 \mathrm{mg} / \mathrm{ml})\end{array}$ & $53.86 \pm 0.41^{\mathrm{a}}$ & $\begin{array}{c}0.2 \mathrm{ml} \\
(20 \mathrm{mg} / \mathrm{ml})\end{array}$ & $63.05 \pm 0.35^{b}$ \\
\hline & & $\begin{array}{c}0.2 \mathrm{ml} \\
(20 \mathrm{mg} / \mathrm{ml})\end{array}$ & $57.77 \pm 0.86^{a}$ & $\begin{array}{c}0.4 \mathrm{ml} \\
(40 \mathrm{mg} / \mathrm{ml})\end{array}$ & $68.94 \pm 0.69^{b}$ \\
\hline & & $\begin{array}{c}0.3 \mathrm{ml} \\
(30 \mathrm{mg} / \mathrm{ml})\end{array}$ & $72.27 \pm 0.17^{\mathrm{a}}$ & $\begin{array}{c}0.6 \mathrm{ml} \\
(60 \mathrm{mg} / \mathrm{ml})\end{array}$ & $82.82 \pm 0.31^{b}$ \\
\hline \multirow{3}{*}{$\frac{\grave{o}}{\dot{\theta}}$} & L (darkness/lightness) & \multicolumn{2}{|c|}{$56.20 \pm 0.06^{\mathrm{a}}$} & \multicolumn{2}{|c|}{$32.67 \pm 0.02^{b}$} \\
\hline & a (redness/greenness) & \multicolumn{2}{|c|}{$15.21 \pm 0.06^{\mathrm{a}}$} & \multicolumn{2}{|c|}{$17.03 \pm 0.03^{b}$} \\
\hline & b (blueness/yellowness) & \multicolumn{2}{|c|}{$18.25 \pm 0.03^{a}$} & \multicolumn{2}{|c|}{$21.79 \pm 0.06^{b}$} \\
\hline
\end{tabular}

- Different letters on same represent statistically significant $(\mathrm{P}<0.05)$ difference between means

DPPH radical scavenging activities of ROSP were determined (Table 4). Scavenging activity increased with increased ROSP concentrations and with increased roasting time to 50 min. These results agreed with total phenols and flavonoids content of ROSP. Sahin et al. (2009) 
INTERNATIONAL JOURNAL OF

FAMILY STUDIES, FOOD SCIENCE AND NUTRITION

HEALTH

ISSN: $2735-5381$

VOLUME 4, ISSUE 2, 2021, $110-123$.

www.egyptfuture.org/ojs/

reported that the antioxidant activity increased as the roasting degree increases because of Maillard reaction products.

Consumer acceptability may be affected by product color. There were remarkable changes in the color parameters of the roasted seeds as shown in Table 4. Roasting time has a significantly difference on color of ROSP, the lightness (L value) of the ROSP was around 56 and this value decreased to 32.67 after increasing roasting time for $50 \mathrm{~min}$. This decrease indicated progressive darkening of ROSP. Increment of roasting time, increased the (a) and (b) values were increased in ROSP. These results agreed with Fikry et al. (2019). Fikry et al. (2019) reported that $L$ values (42-56.99) and (29-36.99) were medium light and medium dark.

The olive seed oil was richer in individual sterols (2.3-fold higher), mainly in $\beta$-sitosterol, which has important effects on absorption of cholesterol and bile acid. It was also richer in total polyunsaturated fatty acids (PUFA), due its higher contents of linoleic acid. On the other hand, it had less triterpene dialchols (3.5-fold lower) than the olive fruit (Rodriguez et al., 2008).

The fatty acid composition of ROSP for different time is shown in Table 5. The main fatty acids in ROSP were oleic acid (C18:1), linoleic acid (C18:2) and palmitic acid (C16:0). The saturated fatty acid (SFA) content of ROSP significantly increased from 13.36 to $14.31 \%$, after roasting for $50 \mathrm{~min}$. On the other hand, TUSFA and TUSFA/TSFA ratio significantly decreased from 86.64 and 6.48 to 85.69 and 5.99 , respectively.

Table (5) Fatty acids (\%) profile of ROSP

\begin{tabular}{|c|c|c|}
\hline Fatty acids & Roasted at $200^{\circ} \mathrm{C} / 25 \mathrm{~min}$ & Roasted at $200^{\circ} \mathrm{C} / 50 \mathrm{~min}$ \\
\hline C14:0 & $0.07 \pm 0.011^{a}$ & $0.05 \pm 0.01^{a}$ \\
\hline C16:0 & $9.88 \pm 0.13^{a}$ & $10.44 \pm 0.07^{b}$ \\
\hline C16:1 & $0.23 \pm 0.00^{\mathrm{a}}$ & $0.21 \pm 0.01^{b}$ \\
\hline C17:0 & $0.08 \pm 0.01^{a}$ & $0.08 \pm 0.01^{a}$ \\
\hline C17:1 & $0.08 \pm 0.00^{a}$ & $0.08 \pm 0.01^{a}$ \\
\hline C18:0 & $2.64 \pm 0.05^{a}$ & $2.89 \pm 0.06^{b}$ \\
\hline C18:1 & $68.11 \pm 0.31^{\text {a }}$ & $65.29 \pm 0.27^{b}$ \\
\hline C18:2 & $17.06 \pm 0.16^{\mathrm{a}}$ & $18.96 \pm 0.02^{b}$ \\
\hline C18:3 & $0.50 \pm 0.05^{\mathrm{a}}$ & $0.46 \pm 0.033^{a}$ \\
\hline C20:0 & $0.47 \pm 0.02^{a}$ & $0.60 \pm 0.04^{b}$ \\
\hline C20:1 & $0.66 \pm 0.04^{a}$ & $0.69 \pm 0.01^{a}$ \\
\hline C22:0 & $0.22 \pm 0.02^{a}$ & $0.25 \pm 0.04^{a}$ \\
\hline TSFA & $13.36 \pm 0.24^{a}$ & $14.31 \pm 0.23^{b}$ \\
\hline TUSFA & $86.64 \pm 0.24^{a}$ & $85.69 \pm 0.23^{b}$ \\
\hline TUSFA/TSFA & $6.48 \pm 0.13^{a}$ & $5.99 \pm 0.11^{b}$ \\
\hline
\end{tabular}




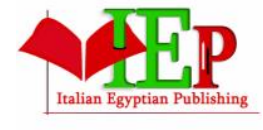

ISSN: $2735-5381$
INTERNATIONAL JOURNAL OF

FAMILY STUDIES, FOOD SCIENCE AND NUTRITION

HEALTH

VOLUME 4, ISSUE 2, 2021, $110-123$.

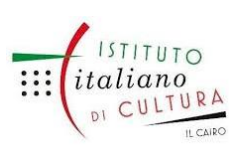

www.egyptfuture.org/ojs/

- Different letters on same represent statistically significant $(\mathrm{P}<0.05)$ difference between means; TSFA: Total Saturated fatty acids; TUSFA: Total Unsaturated fatty acids

The identification of total phenolic acid and quantities from ROSP extract at different roasting times was determined using HPLC and the data are reported in Table (6). All detected phenolic compounds decreased except Chlorogenic when increased roasting time. Chlorogenic was not detected in ROSP for $25 \mathrm{~min}$ and detected in ROSP for $50 \mathrm{~min}(68.71 \mathrm{mg} / \mathrm{kg})$. Bekedam et al. (2008) indicated that the formation of intermediate molecular weight melanoidins might be due to Maillard reactions and chlorogenic acid incorporation reactions between chlorogenic acids, sucrose, and amino acids/protein fragments during the initial roasting of coffee beans. Caffeine content also, was decreased since, it reached $4.4 \mathrm{mg} / \mathrm{kg}$ by increasing roasting time to $50 \mathrm{~min}$. The range of caffeine contents reported for roasted $C$. arabica seeds was $0.7-1.6 \mathrm{~g} / 100 \mathrm{~g}$ while, for those $C$. canephora was 1.8-2.6 g/100g (dePaula and Farah, 2019) Also, (Ragab and Hassan, 2019) found caffeine content in commercial coffee brew $36.02 \mathrm{mg} / \mathrm{g}, 4.47$ and 5.70 $\mathrm{mg} / \mathrm{g}$ in date pits coffee and flavored date pits coffee, respectively. One can conclude that, caffeine content in our results of ROSP are considered exist in very lower concentration compared with data reported. There are many factors affecting caffeine content such as, type of coffee seeds, roasting conditions and serving size. The healthy adult population, moderate daily intake could be at a dose level up to $400 \mathrm{mg}$. The overdose might be associated with adverse effects such as toxicity, cardiovascular disease and change in adult behavior (Nawrot et al ,2003)

Table (6) Phenolic content (mg/kg) of ROSP

\begin{tabular}{|c|c|c|}
\hline Compound & Roasted at $200^{\circ} \mathrm{C} / 25 \mathrm{~min}$ & Roasted at $200^{\circ} \mathrm{C} / 50 \mathrm{~min}$ \\
\hline Pyrogallao & $20.26 \pm 0.29^{a}$ & $4.74 \pm 0.20^{b}$ \\
\hline Gallic & $3.08 \pm 0.13^{a}$ & $0.72 \pm 0.02^{b}$ \\
\hline Catechol & $127.33 \pm 0.81^{a}$ & $35.98 \pm 0.56^{b}$ \\
\hline 4-Aminio-benzoic & $5.96 \pm 0.14^{\mathrm{a}}$ & $2.64 \pm 0.09^{b}$ \\
\hline P-OH-benzoic & $24.67 \pm 0.19^{a}$ & ND* \\
\hline Catechein & ND & ND \\
\hline Chlorogenic & ND & $68.71 \pm 0.30^{b}$ \\
\hline Caffeic & ND & ND \\
\hline Vanillic & $25.91 \pm 0.32^{\mathrm{a}}$ & $7.65 \pm 0.05^{b}$ \\
\hline Caffeine & $89.36 \pm 0.16^{\mathrm{a}}$ & $4.30 \pm 0.09^{b}$ \\
\hline Oleuropin & $137.43 \pm 0.58^{\mathrm{a}}$ & $43.44 \pm 0.23^{b}$ \\
\hline Ferulic & $61.02 \pm 0.22^{a}$ & $6.01 \pm 0.06^{b}$ \\
\hline Coumaric & $19.66 \pm 0.14^{a}$ & $4.13 \pm 0.10^{b}$ \\
\hline
\end{tabular}

-Different letters on same represent statistically significant $(\mathrm{P}<0.05)$ difference between means; *ND: not detected

The sensory attributes of the brew made from ROSP under different roasting times, namely, color, taste, odor, and overall acceptability, were evaluated. Color is a critical attribute that can be used as a quality control indicator during roasting processes (Mendes et al., 2001). Table 7 reveals that coffee control samples has the highest color scores followed by ROSP brew at 50 min then ROSP brew at $25 \mathrm{~min}$. The accepting color of the brew might be due to the increase of browning index, which resulted from Maillard reactions (Manzocco et al., 2000). 
INTERNATIONAL JOURNAL OF

FAMILY STUDIES, FOOD SCIENCE AND NUTRITION

HEALTH

VOLUME 4, ISSUE 2, 2021, $110-123$.

www.egyptfuture.org/ojs/

Table 7. Sensory evaluation of ROSP brew

\begin{tabular}{|c|c|c|c|c|}
\hline Treatments & Color & Taste & Odor & $\begin{array}{c}\text { Overall } \\
\text { acceptability }\end{array}$ \\
\hline $\begin{array}{c}\text { Control (Light roasted } \\
\text { flavorings coffee) }\end{array}$ & $8.67 \pm 0.58^{c}$ & $8.67 \pm 0.58^{c}$ & $8.67 \pm 0.58^{c}$ & $8.33 \pm 0.58^{b}$ \\
\hline $\begin{array}{c}\text { Control (medium roasted } \\
\text { flavorings coffee) }\end{array}$ & $8.33 \pm 0.58^{b c}$ & $8.00 \pm 0.00^{b c}$ & $8.00 \pm 0.00^{b c}$ & $8.00 \pm 0.00^{b}$ \\
\hline $\begin{array}{c}\text { ROSP brew } \\
\left(200^{\circ} \mathrm{C} / 25 \mathrm{~min}\right)\end{array}$ & $6.33 \pm 0.58^{a}$ & $6.67 \pm 0.58^{a}$ & $6.67 \pm 0.58^{a}$ & $6.33 \pm 0.58 a$ \\
\hline $\begin{array}{c}\text { ROSP brew } \\
\left(200^{\circ} \mathrm{C} / 50 \mathrm{~min}\right)\end{array}$ & $7.33 \pm 0.58^{a b}$ & $7.33 \pm 0.58^{\text {a b }}$ & $7.33 \pm 0.58^{b}$ & $7.50 \pm 0.58^{b}$ \\
\hline
\end{tabular}

- Different letters on same represent statistically significant $(\mathrm{P}<0.05)$ difference between means

The taste, odor and overall acceptability are also an important quality indicators of ROSP brew. Results revealed that the highest scores of the Control (Light roasted flavorings coffee) were 8.67, 8.67 and 8.33, respectively followed by control (medium roasted flavorings coffee), ROSP for $50 \mathrm{~min}$ and ROSP for $25 \mathrm{~min}$ (Table 7). It was suggested that the changes in accepting the taste and aroma might be due to $\mathrm{pH}$ decrease of the brews (Bicho et al., 2013). The results of sensory evaluation revealed that the ROSP can be successfully used as a unique natural alternative to coffee

\section{Conclusions}

Roasted olive stones could be considered as an important source of bioactive phenolic compounds, dietary fiber, total carbohydrates, minerals, and antioxidants. The results of sensory evaluation revealed that the ROSP can be used successfully as a unique natural, healthy and low cost alternative to coffee and to avoid the side effects of coffee seeds brew and create an added value to a by-product materials (Olive stone).

\section{References}

Ahsan, F. and Bashir, S. (2019). Coffee consumption: health prospective and drawbacks. $J$ Nutr Obes. 2:101.

Anisa, A.; Solomon, W.K. and Solomon, A. (2017). Optimization of roasting time and temperature for brewed hararghe coffee (Coffea Arabica L.) using central composite design. International Food Research Journal. 24(6): 2285-2294.

AOAC (2012). Official Method of Analysis. $19^{\text {th }}$ Ed., Association of Official Analytical Chemists, Washington DC., USA.

Bekedam, E.K.; Schols, H.A.; Cämmerer, B.; Kroh, L.W.; van Boekel, M.A.; Smit, G. (2008). Electron spin resonance (ESR) studies on the formation of roasting-induced antioxidative structures in coffee brews at different degrees of roast. J. Agric. Food Chem. $56,4597-4604$. 
INTERNATIONAL JOURNAL OF

FAMILY STUDIES, FOOD SCIENCE AND NUTRITION

HEALTH

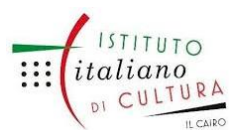

VOLUME 4, ISSUE 2, 2021, $110-123$.

www.egyptfuture.org/ojs/

Benjakul, S.; Lertittikul, W.; Bauer, F. (2005). Antioxidant activity of Maillard reaction products from a porcine plasma protein-sugar model system. Food Chem. 93, 189-196.

Bianchi, G. (2003). Lipids and phenols in table olives. Eur. J. Lipid Sci. Technol. 105, 229-242.

Bicho, N.C.; Leitão, A.E.; Ramalho, J.C.; de Alvarenga, N.B. and Lidon, F.C. (2013). Impact of roasting time on the sensory profile of Arabica and Robusta coffee. Ecol. Food Nutr. 52, 163-177.

Bledzki, A.K. and Gassan, J. (1999). Mechanical behavior of wood/polypropylene composites: effects of fiber treatments and ageing processes. Prog Polym Sci. 24, 221.

Carraro, L.; Trocino, A. and Xiccato, G. (2005). Dietary supplementation with olive stone meal in growing rabbits. Ital. J. Animal Sci. 4, 88-90.

dePaula, J. and Farah, A. (2019) Caffeine consumption through coffee: Content in the beverage , metabolism ,health benefits and risks. Beveragr, 5, 37.doi:10.3390/beverages5020037.

Eghdami, A. and Sadeghi, F. (2010). Determination of total phenolic and flavonoids contents in methanolic and aqueous extract of Achilleamillefolium. Org. Chem. J. 2:81-84.

Eid, M.M.; Elsorady, M.E.I. and Ali, S.E. (2012). Traceability of olive oil authentication using DNA molecular evaluation, thermal analysis (DSC) and ECN42. J. Biological Chemistry \& Environmental Sciences. 7, (4), 259-284.

Elsorady, M.E.I. (2010). Quality of table olives in relation to pickling process and fermentation time. J. of Food and Dairy Sciences, Vol. 1 (3): 131 - 142.

Fikry, M.; Yusof, Y.A.; Al-Awaadh, A.M.; Rahman, R.A.; Chin, N.L.; Mousa, E. and Chang, L.S. (2019). Effect of the Roasting Conditions on the Physicochemical, Quality and Sensory Attributes of Coffee-Like Powder and Brew from Defatted Palm Date Seeds. Foods. 8, 61; doi:10.3390/foods8020061

Gikuru, M. and Jindal, V.K. (2003). Coffee drying in a rotary conduction-type heating unit. Journal of Food Process Engineering. 27: 143-157.

Gonzalez, J.F.; Gonzalez-Garcia, C.M.; Ramiro, A.; Gonzalez, J.; Sabio, E.; Ganan, J. and Rodrguez, M.A. (2003). Combustion optimisation of biomass residue pellets for domestic heating with a mural boiler. Biomass Bioenergy. 27, 145-154.

IOC (2021). International olive council, Available from: https://www.internationaloliveoil.org/wp-content/uploads/2021/12/HO-W901-17-12-2021

Larmond, E. (1997). Laboratory method of sensory evaluation of food Publication 1977, Canada, Dept: Agric. Ottawa. 1997

Liu, X.; Zhao, X.; Wang, J.; Yang, B. and Jiang, Y. (2008). Antioxidant activity of methanolic extract of emblica fruit (PhyllanthusemblicaL.) from six regions in China.J Food CompositionAnal. 21: 219-228.

Lopes, G.R.; Passos, C.P.; Rodrigues, C.; Teixeira, J.A. and Coimbra, M.A. (2020). Impact of microwave-assisted extraction on roasted coffee carbohydrates, caffeine, chlorogenic acids and coloured compounds. Food Research International. 129, 108864. https:// doi.org/10.1016/j.foodres.2019.108864.

Luaces, P., Perez, A.G., Sanz, C., 2003. Role of olive seed in the biogenesis of virgin olive oil aroma. J. Agric. Food Chem. 51, 4741-4745. 
Maestro-Durán, R.; Cabello, L.R; Gutiérrez, R.V. and Roncero, V.A. (1994). Glucósidos fenólicos amargos de las semillas del olivo (Olea europaea). Grasas y Aceites. 45, 332335.

Manzocco, L.; Calligaris, S.; Mastrocola, D.; Nicoli, M.C. and Lerici, C.R. (2000). Review of non-enzymatic browning and antioxidant capacity in processed foods. Trends Food Sci. Technol. 11, 340-346.

Massini, R.; Nicoli, M.; Cassarà, A. and Lerici, C. (1990). Study on physical and physicochemical changes of coffee beans during roasting. note 1. Ital. J. Food Sci. 2, 123-130.

Mendes, L.C.; de Menezes, H.C.; Aparecida, M. and Da Silva, A. (2001). Optimization of the roasting of robusta coffee (C. canephora conillon) using acceptability tests and RSM. Food Qual. Prefer. 12, 153-162.

Montane, D.; Salvado, J.; Torras, C. and Farriol, X. (2001). High-temperature dilute-acid hydrolysis of olive stone for furfural production.. Biomass Bioenergy. 22, 295-304.

Münchow, M.; Alstrup, J.; Steen, I. and Giacalone, D. (2020). Roasting Conditions and Coffee Flavor: A Multi-Study Empirical Investigation. Beverages. 6, 29; doi:10.3390/beverages6020029

Nawort, P.; Jordan, S.; Eastwood, J.; Rotstein, J.; Hugenholtz, A. and Feeley, M. (2003) Effects of caffeine on human health. Food Additives and contaminants, 20,1-30.

Özdemir, M. and Devres, O. (2000). Analysis of color development during roasting of hazelnuts using response surface methodology. J. Food Eng. 45, 17-24.

Peres, F.; Martins, L.L.; Mourato, M.; Vitorino, C. and Ferreira-Dias, S. (2016). Bioactive Compounds of Portuguese Virgin Olive Oils Discriminate Cultivar and Ripening Stage. $J$ Am Oil Chem Soc. 93, 1137-1147.

Putun, A.E.; Burcu, B. ; Apaydin, E. and Putun, E. (2005). Bio-oil from olive oil industry waste: pyrolysis of olive residue under different conditions. Fuel Process. Technol. 87, 2532.

Ragab, T.I.M. and Hassan, N.S.Y (2019) A comparative study between different additives for date pits coffee beverage : Health and nutritional evaluation. Egypt . J. Chem. 63, 1-14.

Reyes, C.M. and Cornelis, M.C. (2018). Caffeine in the diet: Country-level consumption and guidelines. Nutrients. 10, 1772.

Rodriguez, G.; Lama, A.; Rodríguez, R.; Jiménez, A.; Guillén, R. and Bolanos, J.F. (2008). Olive Stone an attractive source of bioactive and valuable compounds. Bioresource Technology. 99: 5261-5269.

Sahin, H.; Topuz, A.; Pischetsrieder, M. and Özdemir, F. (2009). Effect of roasting process on phenolic, antioxidant and browning properties of carob powder. Eur. Food Res. Technol. 230, 155.

Sanchez, M.L.D.; Macas-Garcia, A.; Diaz-Diez, M.A.; Cuerda-Correa, E.M.; GananGomez, J. and Nadal-Gisbert, A. (2006). Preparation of activated carbons previously treated with hydrogen peroxide: study of their porous texture. Appl. Surf. Sci. 252, 59845987.

Servili, M.; Baldioli, M.; Selvaggini, R.; Macchioni, A. and Montedoro, G. (1999). Phenolic compounds of olive fruit: one- and two-dimensional nuclear magnetic resonance 


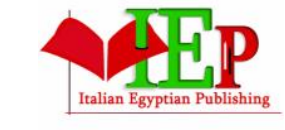

ISSN: 2735-5381

\section{INTERNATIONAL JOURNAL OF \\ FAMILY STUDIES, FOOD SCIENCE AND NUTRITION \\ HEALTH}

VOLUME 4, ISSUE 2, 2021, 110-123.

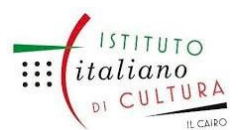

www.egyptfuture.org/ojs/

characterization of Nuzhenide and its distribution in the constitutive parts of fruit. Journal of Agricultural and Food Chemistry. 47: 12-18.

Shahidi, F. and Naczk, M. (2004). Phenolics in Food and Nutraceuticals; CRC Press Inc.: Boca Raton, FL, USA. 2004; pp. 13-141.

Siracusa, G.; La Rosa, A.D.; Siracusa, V. and Trovato, M. (2001). Eco- Compatible use of olive huso as filler in thermoplastic composites. J. Polym. Environ. 9, 157-161.

USDA Foreign Agricultural Department (2020) Coffee: world markets and trade. December,2020, 1-3.

Xu, B.J. and Chang, S.K.C. (2007). A Comparative Study on Phenolic Profiles and Antioxidant Activities of Legumes as Affected by Extraction Solvents.Journal of Food Science. 72, S159-S166. 